\title{
Genotypic Effect of Rootstock and Scion on Grafting Success and Growth of Kola (Cola nitida) Seedlings
}

\author{
Abu Mustapha Dadzie, Abraham Akpertey, Julius Yeboah, Stephen Yaw Opoku, \\ Atta Ofori, Samuel Lowor, Richard Ackyeampong, Patricia Adu-Yeboah, \\ Mercy Asamoah, Frank Manu Amoah \\ Cocoa Research Institute of Ghana (CRIG), Tafo-Akim, Ghana \\ Email: xmusto@yahoo.co.uk
}

Received 5 November 2014; revised 4 December 2014; accepted 11 December 2014

Copyright (C) 2014 by authors and Scientific Research Publishing Inc.

This work is licensed under the Creative Commons Attribution International License (CC BY). http://creativecommons.org/licenses/by/4.0/

(c) (i) Open Access

\section{Abstract}

Kola (Cola nitida) is an important economic cash crop for many West and Central African countries. It has several medicinal uses in the pharmaceutical industries and also plays a major role in traditional marriages among Islamic communities across West and Central Africa. The crop is extensively cultivated in Nigeria and Ghana. However, it exhibit signs of total and partial sterility as well as self incompatibility when propagated from seeds in most cases. Therefore, grafting is seen as a method of choice in addressing the problem stated above. Though grafting accounts for some degree of success, there is the need to assess genotypic and physiological factors that account for high or low grafting success. Genetic and physiological factors (such as rootstock age) affecting grafting success and growth in kola ( $C$. nitida) were investigated in two separate experiments. In experiment 1720 kola seedlings were raised from unselected kola nuts and sown at two monthly intervals. Four groups of seedlings (180/group) i.e. 6, 8, 10 and 12 months old were thus produced. Three different scions (A1, A12 and JB1) measuring $(5-10 \mathrm{~cm})$ were grafted onto the four age groups of rootstocks, namely, 6, 8, 10 and 12 months. Experiment II consisted of 540 seedlings raised from three main crosses (JX1/9 × JX1/11* B1/142 × B1/151, JX1/9 × JX1/11* B2/177 × $\mathrm{B} 2 / 156$ and JX1/9 $\times \mathrm{JX1} / 11 * \mathrm{GX1} / 46 \times \mathrm{GX1} / 53)$. Grafting was done after six months using the same set of scions as described in experiment I. Experimental design used was $3 \times 4$ and $3 \times 3$ factorial designs in completely randomised design with three replicates for experiment I and II respectively. The fixed effects were the different genotype and age of rootstock at grafting whilst the response variable was the percentage of successful grafting two months as well as growth at six monthly intervals. Results from the study showed that grafting onto 6 months old stocks gave the highest percentage success and growth of grafts followed by 8,10 and 12 months old rootstock in that order in both trial years. The study revealed also a significant rootstock and scion interaction $(P<0.05)$. We conclude that successful grafting in kola depends on rootstock genotype such as 
$\mathrm{JX1} / 9 \times \mathrm{JX1} / 11 * \mathrm{GX1} / 46 \times \mathrm{GX1} / 53$ and has been proven suitable for use in future kola propagation studies. Nonetheless, suitable rootstock with high grafting success does not translate into vigorous scion growth.

\author{
Keywords
}

Kola, Rootstock, Scion, Genotype

\title{
1. Introduction
}

Kola (Cola nitida Ventenant) is a tropical cash crop in Africa that belongs to the Sterculiaceae family. The genus comprises of about 140 species [1] out of which 50 species have been described in West Africa by Adebola, [2]. It is estimated that Nigeria alone produces almost $70 \%$ of the world's kola nuts with an annual production around 200,000 metric tonnes of fresh kola per year. Ghana's, production figures are not readily available due to unregulated market of the produce. The crop is cultivated mainly in the Eastern, Volta, Ashanti, Brong Ahafo and Western regions of Ghana where it serves as the main livelihood of many farmers and traders. In the year 2006, producer price of kola in Ghana was US \$1123.01 per tonne [3].

Despite the economic importance of kola, several agronomic factors limit its production. These include old age of trees, self and cross incompatibility of trees, partial and total sterility, inefficient natural pollination and use of poor planting materials. Traditionally kola is grown by seeds and more rarely by vegetative means. Research at the Cocoa Research Institute of Ghana, has previously focused on seed propagation. However, reports indicate that germination is highly variable and may take up to three months [4]. Furthermore, trees propagated from seeds exhibit high sterility and incompatibility traits at maturity and could render entire plantation unproductive.

Removal of testa, as well as splitting and cutting of nuts have been employed in the past to reduce the germination time and ensure uniform germination [4]. Some degree of success was achieved, but this did not appear to address the compatibility and incompatibility issues at maturity.

To address incompatibility problems in kola and to maintain homogeneity in growth to perpetuate other desirable genetic characteristics, vegetative propagation methods are envisaged [5]. These methods include (budding, stem cuttings and grafting). Budding in kola, is feasible, but buds sometimes break or develop into flowers instead of shoot [5]. Stem cuttings, an alternate method is also difficult to root when used for propagation, hence, the use of grafting as the method of choice. At the Cocoa Research Institute of Ghana, grafting success in kola ranges between $50 \%$ to about $90 \%$ [6]. The cause of this wide variation is yet to be understood. Nanda \& Tandon, [7] and Nanda [8] have reported that grafting success in tree crops is genetically controlled. Therefore in view of the variation existing in kola grafting success, two experiments were designed to determine the suitable age of root stock which will enhance grafting success and also to determine the effect of root stock genotype on percentage success.

\section{Materials and Methods}

Two sets of experiments were conducted at the kola nursery of the Cocoa Research Institute of Ghana between the year 2011 and 2014. Experiment I was conducted from 2011 to 2012 and repeated in 2013 to 2014 to determine the suitable age of root stock for enhanced grafting whilst experiment II was conducted between 2011 to 2013 to determine the effect of rootstock genotype on grafting success.

In experiment I, kola nuts weighing $15 \mathrm{~g}$ to $20 \mathrm{~g}$ were selected and sowed in four batches of 180 nuts per batch at two monthly intervals into poly bags of dimension $7 \times 10 \mathrm{~cm}$ filled with evenly mixed top soil. A total of 720 nuts were sown and monitored until the first batch was 12 months old whilst the remaining batches were 10, 8 and 6 months old respectively. Three groups of scions consisting of two hundred and forty (greenish brown) from each of the three high yielding and cross compatible genotypes (A1, A2 and A12) were selected.

These were cut into a wedge shape and measured between $10 \mathrm{~cm}$ to $15 \mathrm{~cm}$ in length and were used in grafting 20 seedlings per genotype per age in three replications. Budding tape of dimension $(1.5 \mathrm{~cm} \times 25 \mathrm{~cm})$ was used to tire the graft union between the rootstock and scion. After care activities were done during and after grafting 
to enhance success. Experimental design used was $3 \times 4$ factorial in complete randomised design with three replicates.

In experiment II, five hundred and forty (540) nuts consisting of three main groups (genotypes) of 180 nuts per genotype were used. $(\mathrm{JX} 1 / 9 \times \mathrm{JX} 1 / 11 * \mathrm{~B} 1 / 142 \times \mathrm{B} 1 / 151, \mathrm{JX} 1 / 9 \times \mathrm{JX} 1 / 11 * \mathrm{~B} 2 / 177 \times \mathrm{B} 2 / 156$ and JX1/9 $\times$ $\mathrm{JX} 1 / 11 * \mathrm{GX} 1 / 46 \times \mathrm{GX} 1 / 53)$ The three genotypes were developed through manual hand pollination. The nuts were planted in poly bags of dimension $7 \times 10 \mathrm{~cm}$ filled with evenly mixed top soil. The nuts raised weighed between $15 \mathrm{~g}$ to $20 \mathrm{~g}$ and were monitored for six months after germination. The seedlings at six months old were used for grafting with the three groups of scions same as described in experiment I above. The set up was arranged in a $3 \times 3$ factorial in CRD with three replicates. Each set of root stock was grafted with 20 scions of a particular genotype.

\subsection{Girth Increment after Grafting}

Growth performance was monitored by measuring the rate of girth increase with a pair of Pro-Max NSK callipers, at $15 \mathrm{~cm}$ above the soil surface in the poly bag. This exercise was done at six monthly intervals for a period of two years for both experiments.

\subsection{Statistical Analysis}

Data Analysis

The data generated were analyzed using GenStat Release 11.0 for Windows (VSN International). Data for the replicate experiments were combined in a single analysis because no significant interactions were found between the different experiments. The data were checked for homogeneity of variance and normality of residuals. All data were analyzed by parametric interaction analysis of variance (ANOVA) and the differences between treatment means detected using least significant difference at $\mathrm{P}<0.05$.

\section{Results}

\subsection{Response of Scion to Root Stock age (Experiment I)}

Assessment of rootstock type on grafting success in kola revealed significant effect of root stock on grafting success or "take". In Table 1, significant interactions were observed between the rootstock and the scion at $(\mathrm{P}<$ 0.05). Percentage means of rootstock age on success ranged between $81.1 \%$ (12 months) to $91.7 \%$ (6 months) whilst percentage means of successful scion ranged between 76.2 (JB1) to 95.4 (A1), Grafting success with regards to specific scion genotypes was low for JB1 whilst it was high for A1 (Table 1).

Root stock effect on percentage success showed a gradual decline in success as the rootstock aged or matured. Though difference between 6 and 8 months old rootstocks were not significant, the 6 months old stocks seem to support high grafting success Table 1 and Table 2.

In Table 2, significant effect of rootstock age was observed in the percentage success at $(\mathrm{P}<0.05)$. This varied from 73.3\% (12 months) to 86.7\% (6 months). Percentage success for scions was also significant at $(\mathrm{P}<0.05)$ and ranged between 72.1 (JB1) to 92.1 (A1). This observation is similar to the trend observed in Table 1. The trend demonstrated by the scions seems to indicate that grafting success to a large extend depends on the

Table 1. Percentage response of scion to various age of unselected kola rootstock seedling (2011-2012).

\begin{tabular}{|c|c|c|c|c|}
\hline \multicolumn{5}{|c|}{ Scion } \\
\hline Age & $\mathrm{A} 1$ & A12 & JB1 & Means of age \\
\hline 12 months & 91.7 & 91.7 & 60.0 & 81.1 \\
\hline 10 months & 98.3 & 96.7 & 66.7 & 87.2 \\
\hline 8 months & 93.3 & 88.3 & 90.0 & 90.6 \\
\hline 6 months & 98.3 & 88.3 & 88.3 & 91.7 \\
\hline Means of scion & 95.4 & 91.2 & 76.2 & \\
\hline CV\% & \multicolumn{4}{|c|}{2.3} \\
\hline LSD (0.05) & \multicolumn{4}{|c|}{ Scion $=6.4$, Age = 7.4, Age. Scion = 12.84} \\
\hline
\end{tabular}

$\mathrm{CV}(\%)$ represents percentage co-efficient of variation, whilst LSD = least significant difference. 
Table 2. Percentage response of scions to various age of unselected kola rootstock seedling (2013 - 2014).

\begin{tabular}{|c|c|c|c|c|}
\hline \multicolumn{5}{|c|}{ Scion } \\
\hline Age & A1 & A12 & JB1 & Means of age \\
\hline 12 months & 90.0 & 81.7 & 48.3 & 73.3 \\
\hline 10 months & 95.0 & 80.0 & 63.3 & 79.4 \\
\hline 8 months & 90.0 & 81.7 & 85.0 & 85.6 \\
\hline 6 months & 93.3 & 75.0 & 91.7 & 86.7 \\
\hline Means of scion & 92.1 & 79.6 & 72.1 & \\
\hline CV\% & \multicolumn{4}{|c|}{5.2} \\
\hline LSD (0.05) & \multicolumn{4}{|c|}{ Scion $=7.6$; Age $=8.7$; Age. Scion $=15.1$} \\
\hline
\end{tabular}

CV (\%) represents percentage co-efficient of variation, whilst LSD = least significant difference.

genotype used as reported by Wang [9]. Genotype A1 seem to perform significantly better compared to JB1 across all ages of rootstock whilst A12 performed moderately well with respect to the two genotypes.

\subsection{Average Growth of Scion (Experiment I)}

Results of statistical analysis of scion growth over a two year period did not show any significant difference (P < 0.05 ) in the vigour (girth size) at the different rootstocks ages tested in the present study. The average scion growth ranged between $8.91 \mathrm{~mm}$ to $8.98 \mathrm{~mm}$.

Though there were no differences, A1 recorded a slightly bigger girth compared to the rest (Table 3). This observation seem to suggest that some scions respond better in terms of grafting "take" than others irrespective of rootstock used.

\subsection{Average Growth of Rootstock (Experiment I)}

Significant differences were found in the growth of rootstock at $(\mathrm{P}<0.05)$. The average girth size over a two year period ranged between $8.19 \mathrm{~mm}$ to $9.73 \mathrm{~mm}$. Interestingly, growth was much rapid in the younger rootstocks but declined with age (Table 3).

\subsection{Effect of Rootstock Genotype on Percentage Scion Success (Experiment II)}

Assessment of the role of rootstock genotype on grafting success showed significant effect $(\mathrm{P}<0.05)$ on the percentage success of scions (Table 4). Furthermore, significant interaction between rootstock and scion was also observed at $(\mathrm{P}<0.05)$. Means of rootstock effect ranged between $41.7 \%(\mathrm{JX} 1 / 9 \times \mathrm{JX} 1 / 11 * \mathrm{~B} 2 / 177 \times$ B2/156) to $72.8 \%(\mathrm{JX} 1 / 9 \times \mathrm{JX} 1 / 11 * \mathrm{GX} 1 / 46 \times \mathrm{GX} 1 / 53)$. This wide variation indicates the significant role of rootstock genotype in kola propagation.

Percentage means of successful scions also ranged between $47.8 \%$ (A1) to (JB1) $57.8 \%$ which is an indication that some scions interacts better with some specific rootstocks than others as could be seen with JB1 which has performed relatively poor in Tables 1-3 except for this experiment.

\subsection{Influence of Rootstock Genotype on Scion Success and Growth}

Rootstock effect seems paramount on grafting success. Furthermore, scion growth and development also showed significant differences $(\mathrm{P}<0.05)$ in girth size of scions (A1, A12 and JB1) (Table 5).

Average scion increment after two years varied from $5.03 \mathrm{~mm}(\mathrm{JX} 1 / 9 \times \mathrm{JX} 1 / 11 * \mathrm{GX} 1 / 46 \times \mathrm{GX} 1 / 53)$ to 6.24 $\mathrm{mm}(\mathrm{JX} 1 / 9 \times \mathrm{JX} 1 / 11 * \mathrm{~B} 1 / 142 \times \mathrm{B} 1 / 151)$. Ironically, the genotype which supported high grafting success in experiment II recorded the least scion growth after year two. This implies that the rootstock may influence the shoot to grow into a moderate vigor plant [10] [11].

\section{Discussion}

Vegetative propagation techniques have consistently been applied in the multiplication of several plant species with the objective of maintaining their genetic identity. Grafting which is an aspect of vegetative propagation 
Table 3. Growth response of scions to four different age groups of unselected kola rootstock seedling (mm) (2011-2013).

\begin{tabular}{|c|c|c|c|c|}
\hline \multicolumn{5}{|c|}{ Scion } \\
\hline Age & A1 & A12 & JB1 & Means of age \\
\hline 12 months & 8.50 & 8.19 & 7.79 & 8.19 \\
\hline 10 months & 9.24 & 8.53 & 7.95 & 8.63 \\
\hline 8 months & 9.15 & 8.31 & 8.88 & 8.80 \\
\hline 6 months & 9.00 & 9.56 & 10.83 & 9.73 \\
\hline Means of Scion & 8.98 & 8.66 & 8.91 & \\
\hline CV\% & \multicolumn{4}{|c|}{22.57} \\
\hline LSD (0.05) & \multicolumn{4}{|c|}{ Genotypes $=0.46$; Scion $=\mathbf{n s ; ~ A g e . ~}$ Scion $=0.75$} \\
\hline
\end{tabular}

CV (\%) represents percentage co-efficient of variation, whilst LSD = least significant difference, $\mathbf{n s}=$ not significant.

Table 4. Percentage response of scions to selected kola rootstock seedling (2011-2013).

\begin{tabular}{ccccc}
\hline & \multicolumn{5}{c}{ Scion } & Means of genotype \\
\hline Genotype & A1 & A12 & JB1 & $\mathbf{4 3 . 9}$ \\
\hline $\mathrm{JX} 1 / 9 \times \mathrm{JX} 1 / 11 * \mathrm{~B} 1 / 142 \times \mathrm{B} 1 / 151$ & 51.7 & 33.3 & 46.7 & $\mathbf{4 1 . 7}$ \\
$\mathrm{JX} 1 / 9 \times \mathrm{JX} 1 / 11 * \mathrm{~B} 2 / 177 \times \mathrm{B} 2 / 156$ & 43.3 & 33.3 & 48.3 & $\mathbf{7 2 . 8}$ \\
$\mathrm{JX} 1 / 9 \times \mathrm{JX} 1 / 11 * \mathrm{GX} 1 / 46 \times \mathrm{GX} 1 / 53$ & 78.3 & 76.7 & 63.3 & $\mathbf{5 2 . 8}$ \\
Means of scion & $\mathbf{5 7 . 8}$ & $\mathbf{4 7 . 8}$ & $\mathbf{8 . 4}$ \\
CV\% & & & Genotypes = 9.6; Scion = 9.8; Age. Scion = $\mathbf{1 6 . 1}$ \\
LSD (0.05) & &
\end{tabular}

CV (\%) represents percentage co-efficient of variation, whilst LSD = least significant difference.

Table 5. Growth response of scions to selected kola rootstock seedling (mm) (2011-2013).

\begin{tabular}{|c|c|c|c|c|}
\hline \multicolumn{5}{|c|}{ Scion } \\
\hline Genotype & A1 & A12 & JB1 & Means of genotype \\
\hline $\mathrm{JX} 1 / 9 \times \mathrm{JX} 1 / 11 * \mathrm{~B} 2 / 177 \times \mathrm{B} 2 / 156$ & 5.10 & 5.41 & 5.23 & 5.20 \\
\hline $\mathrm{JX} 1 / 9 \times \mathrm{JX} 1 / 11 * \mathrm{GX} 1 / 46 \times \mathrm{GX} 1 / 53$ & 5.45 & 4.84 & 4.72 & 5.03 \\
\hline $\mathrm{JX} 1 / 9 \times \mathrm{JX} 1 / 11 * \mathrm{~B} 1 / 142 \times \mathrm{B} 1 / 151$ & 5.76 & 7.99 & 5.21 & 6.24 \\
\hline Means of scion & 5.45 & 6.08 & 5.05 & \\
\hline CV\% & & & 20 & \\
\hline LSD (0.05) & \multicolumn{4}{|c|}{ Genotypes $=\mathbf{0 . 7 9} ;$ Scion $=\mathbf{0 . 7 8} ;$ Age. Scion $=1.15$} \\
\hline
\end{tabular}

CV (\%) represents percentage co-efficient of variation, whilst LSD = least significant difference.

method has since been applied in kola propagation in order to maintain parental identity which is essential for addressing issues relating to kola compatibility, incompatibility and sterility typical in kola propagated by seeds. Grafting enables compatible genotypes maintain their genetic constitution to enhance yield in kola plantations. Results obtained from experiment I indicates that high grafting success is enhanced at 6 months old, whilst it declined gradually as the rootstock aged. Furthermore it was notable that success also depends on the compatibility of scion genotype and rootstock used.

For example, A1 and A12 seem to be compatible with the rootstocks compared to the JB1 which recorded the least success across all ages investigated.

According to More [12] [13], the developmental stage for compatible grafting in herbaceous plants involves the formation of isolation layer, adhesion of scion and rootstock and reconnection of vascular bridge between scion and rootstock. Furthermore, it was observed by More and Walker [14] that initial adhesion between scion and rootstock occur within a day after grafting and this was related to a pronounced dictyosome activity in cells near the graft interface. These processes probably seem to have occurred much quicker between the 6 months old rootstock and scion and perhaps accounted for the high success due to probable presence of more meristermatic cells compared to the older rootstocks whose cells might be differentiating with age. Failure of grafts is sometimes attributed to the inability of the scions to receive water from the rootstocks before the graft union is 
formed [15] [16]. However, in this present investigation, water stress was likely not an issue but rather the age of the rootstock.

Further observation made in experiment I seem to agree with the findings of [9] which stated that factors such as genetic and physiological affects success. It was therefore not unusual for scion A1 and the 6 months rootstock to record high success.

Despite the high compatibility record demonstrated by scion A1, its subsequent growth (girth increment) was not significant from the other scions indicating that compatibility does not simply translate into rapid scion growth. On the other hand rootstock age affected rate of subsequent growth (girth increment) and was noticeable in the 6 months rootstock, suggesting that grafting of the latter is more beneficial relatively.

In experiment II, It was highly evident that rootstock accounted for success in grafting according to the results obtained. Genotype JX1/9 × JX1/11 * GX1/46 × GX1/53 recorded the highest success and was significantly different from the other two genotypes raised as rootstock, indicating that, to achieve a high degree success in kola grafting, specific crosses need to be made.

This finding is in agreement with Vazifeshenas [17] who demonstrated that specific rootstock significantly affected growth, yield and fruit quality of pomegranate. Growth indeed was significant amongst the rootstocks with JX1/9 $\times$ JX1/11 * B1/142 × B1/151 exhibiting high vigor with respect to the other stocks. Percentage success of grafting and scion growth confirmed profound interaction between rootstock and scion. This is because scion JB1 which performed relatively poor in experiment I seemed to have performed much better with specific rootstock in experiment II than the unselected stocks in experiment I. Vazifeshenas [17] observed a similar trend in pomegranate and reported that how the rootstock controls grafting success and scion growth is not fully understood, however, Kamboj and Quinlan [18] explained that hormones are involved in the control of scion growth, since they found a higher concentration of cytokinin in root exudates from vigorous rootstocks than from dwarfing ones. Moreover, they also showed a lower ratio of Abscisic Acid (ABA) to Indole Acetic Acid (IAA) in vigorous rootstocks compared to dwarf rootstocks. Many other reports have confirmed this phenomenon [19] [20].

It can therefore, be deduced that different rootstocks and scions may produce different levels of hormones which interacts either positively or negatively to account for high or low success in grafting and also affect subsequent growth and development.

\section{Conclusion}

We conclude here that, high degree of grafting success in kola is achievable with six months old rootstocks irrespective of genotype involved. Furthermore, it is evident that rootstock age and scion type play a critical role in attaining success. More so, grafting onto 6 months stocks saves time and cost compared to 8, 10 and 12 months olds. Genotype A1 (scion) was found to be the most compatible scion among the three used. It was also realized that some specific rootstocks (JX1/9 $\times \mathrm{JX} 1 / 11 * \mathrm{GX} 1 / 46 \times \mathrm{GX} 1 / 53)$ account for high percentage success irrespective of scions used but subsequent growth and development are possibly controlled by hormones, therefore rootstocks which show high degree of compatibility do not necessary exhibit vigorous growth. It is therefore, necessary to study the type of hormones produced during grafting in kola and its effect on success.

\section{Acknowledgements}

We wish to thank Mr. Johnson Okai of the Plant Pathology Division of CRIG and Mr. Asirifi of the Plant Breeding Division at CRIG for their Technical assistance. We also want to thank all the Technical staff of the Kola Development Unit at CRIG for their support and assistance especially. This paper is published with permission of the Executive Director of Cocoa Research Institute of Ghana (CRIG) as manuscript number CRIG/11/2014/033/006.

\section{References}

[1] Onomo, P.F., Niemenak, N. and Ndoumou, D.O. (2006) Isoenzyme Variability of Three Cola (Cola Acuminate (Pal de Beauv, Schott and Endlicher), Cola nitida (Vent) Schott and Endlicher) and Cola anomala (Schott and Endlicher) Germplasm in Cameroon. Pakistan Journal of Biological Sciences, 3, 391-397.

[2] Adebola, P.O. (2003) Genetic Characterization and Biosystematic Studies in the Genus Colaschott and Endlicher. Ph.D. Thesis, Submitted to the University of Ibadan, Ibadan, 203.

[3] F.A.O. (2009) Food and Agriculture Organization of the United Nations. http://faostat.fao.org 
[4] Osei-Bonsu, K. and Afrifa, A. (1988) The Germination of Kola Nuts (Cola nitida Ventenant) Schott and Endlicher. Ghana Journal of Agricultural Science, 20-23, 33-38.

[5] Amoah, F.M., Osei-Bonsu, K., Akrofi, A.Y. and Abdul-Karimu, A. (2004) Vegetative Propagation of Kola. Ghana Journal of Agricultural Science, 38, 43-53.

[6] Dadzie, M.A., Akpertey, A., Anim Kwapong, G.J., Safo, J.E., Assuah, M.K. and Amoah, F.M. (2013) Vegetative Propagation of Kola. CRIG Progress Report 2012 - 2013 and Work Plan 2013-2014, 266-268.

[7] Nanda, K.K. and Tandon, R. (1967) Mechanism of Auxin Action on Rooting of Cutting. Proceedings of International Symposium on Plant Growth substances, Calcuta University, Kolkata, 250.

[8] Nanda, K.K., Purohit, A.N., Bala, A. and Anad, V.K. (1968) Seasonal Rooting Response of Stem Cuttings of Some Forest Tree Species to Auxin. Indian Forester, 94, 154-162.

[9] Wang, Y.Q. (2011) Plant Grafting and Its Application in Biological Research. Chinese Science Bulletin, 33, 35113517. http://dx.doi.org/10.1007/s11434-011-4816-1

[10] Hatton, R.G. (1927) Rootstock for Pears. Regport of East Mailing Research Station A, 18, 75-86.

[11] Bitters, W.P. (1969) Citrus Rootstocks for Dwarfing. California Agriculture, 4, 5-14.

[12] Moore, R. (1983) Physiological Aspects of Graft Formation. In: Moore, R., Ed., Vegetative Compatibility Responses in Plants, Baylor University Press, Waco, 89-105.

[13] McCully, M.E. (1983) Structural Aspects of Graft Development. In: Moore, R., Ed., Vegetative Compatibility Responses in Plants, Baylor University Press, Waco, 71-78.

[14] Moore, R. and Walker, D.B. (1981) Studies for Vegetative Compatibility-Incompatibility in Higher Plants. A Structural Study of a Compatible Autograft in Sedum telephoides (Crassulceae). American Journal of Botany, 68, 820-830. http://dx.doi.org/10.2307/2443188

[15] Barnett, J.R. and Weatherhead, I. (1989) The Effect of Scion Water Potential on Graft Success in Sitka Spruce (Picea sitchensis). Annals of Botany, 64, 9-12.

[16] Mergen, F. (1955) Grafting Slash Pine in the Field and in the Greenhouse. Journal of Forestry, 53, 836-842.

[17] Vazifeshenas, M., Khayyat, M., Jamalian, S. and Samadzadeh, A. (2009) Effects of Different Scion—Rootstock Combinations on Vigor, Tree Size, Yield and Fruit Quality of Three Iranian Cultivars of Pomegranate. Technical Paper, 64, 343-349.

[18] Kamboj, S.J. and Quinlan, J.D. (1997) The Apple Rootstock and Its Influence on Endogenous Hormones. Acta Horticulturae, 463, 143-152.

[19] Son, L. and Kuden, A. (2003) Effects of Seedling and GF-31 Rootstocks on Yield and Fruit Quality of Some Table Apricot Cultivars Grown in Mersin. Turkish Journal of Agriculture and Forestry, 27, 261-267.

[20] Kurlus, R. (2008) Rootstock Effects on Growth, Yield and Fruit Quality of Two Sweet Cherry Cultivars in Western Poland. Acta Horticulturae, 795, 293-298. 
Scientific Research Publishing (SCIRP) is one of the largest Open Access journal publishers. It is currently publishing more than 200 open access, online, peer-reviewed journals covering a wide range of academic disciplines. SCIRP serves the worldwide academic communities and contributes to the progress and application of science with its publication.

Other selected journals from SCIRP are listed as below. Submit your manuscript to us via either submit@scirp.org or Online Submission Portal.
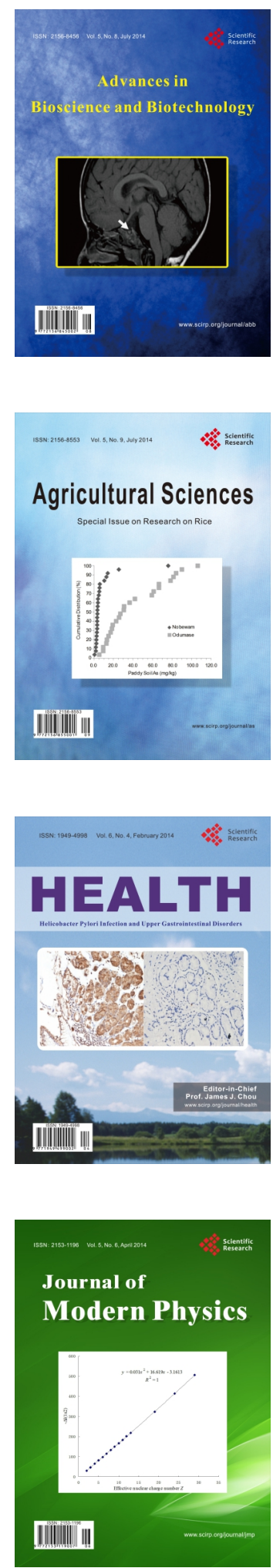
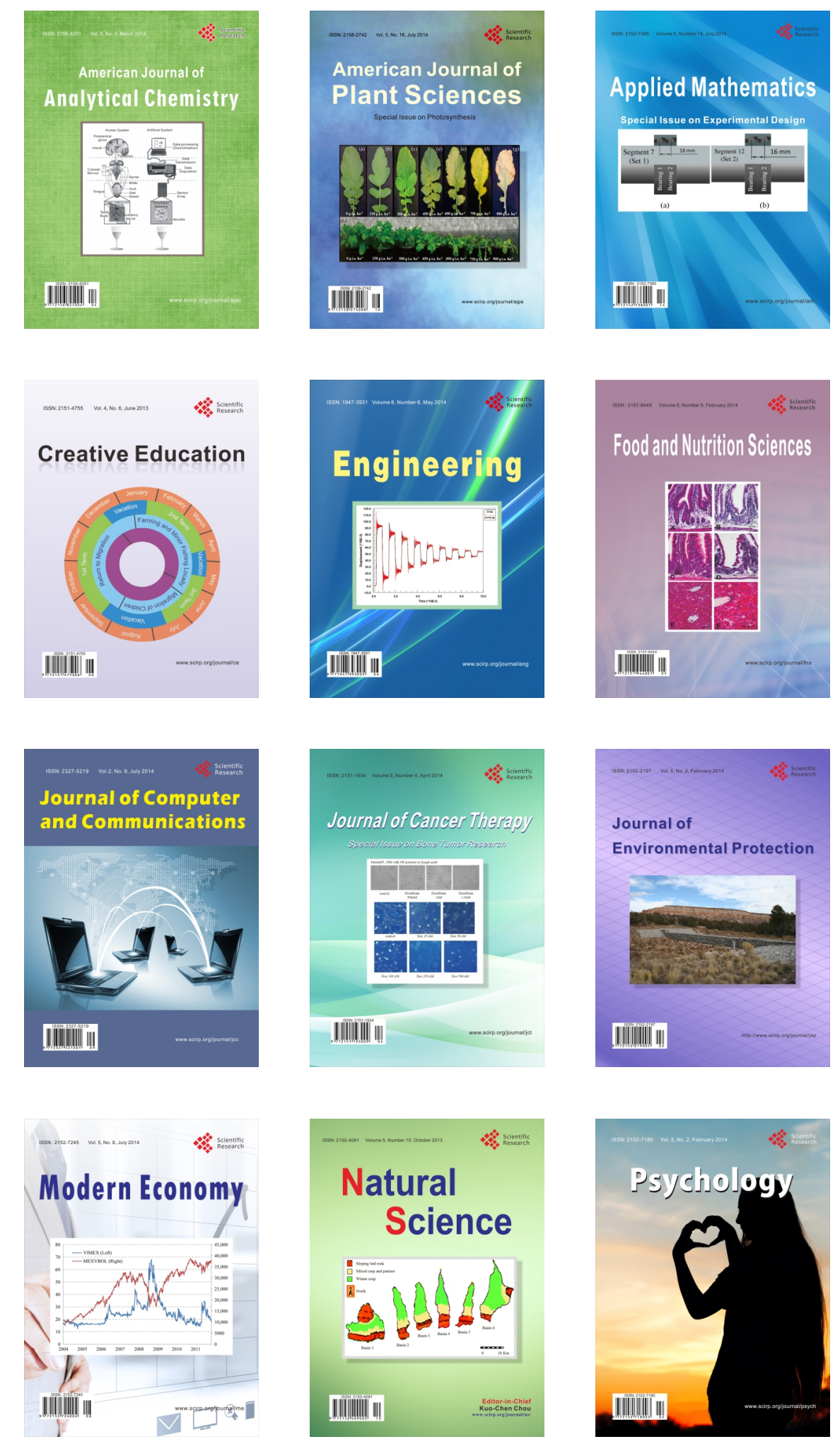